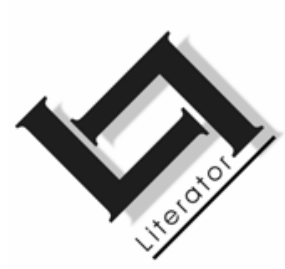

\title{
"Naming of parts", or, how things shape up in transcultural literary history
}

\author{
Leon de Kock \\ Department of English Studies \\ University of South Africa \\ PRETORIA \\ E-mail: dkockl@unisa.ac.za
}

\begin{abstract}
"Naming of parts" ${ }^{1}$, or, how things shape up in transcultural literary history
\end{abstract}

This article suggests that transcultural literary history, in itself an exercise of great complexity, is rendered even more challenging if one accepts that cognition is a critical prior step in the process, regardless of whether literary history is conceived in empirical or in poststructuralist terms. Further, it is argued that cognition depends on analogical processes - to such an extent that literary "history" can be understood as a self-revising cascade of "windows" which recreate the field cognitively over and over again. In this understanding, "literary history", and transcultural literary history in particular, become metacognitive. Rather than a search for "true" structure, literary history is a search for imagined structure which is true to one's mode of perception in the first instance, and to the data at hand in the second. These propositions are argued in relation to South African literary historiography in English.

\section{Opsomming}

"Naming of parts", of, die stand van sake in transkulturele literatuurgeskiedskrywing

In hierdie artikel word aangevoer dat transkulturele literatuurgeskiedskrywing, wat op sigself 'n komplekse taak is,

1 An allusion to Henry Reed's "Naming of Parts". 
nog meer ingewikkeld begin raak as 'n mens aanvaar dat kognisie, of die funksie en prosesse van verstandelike waarneming, 'n bepalende rol speel in die proses - of hierdie proses nou in empiriese of poststrukturele terme gesien word. Verder word beredeneer dat kognisie op analogiese prosesse gegrond is - tot so 'n mate dat literatuurgeskiedskrywing beskou kan word as 'n proses waarin 'n reeks "vensters" ("windows") hulleself voortdurend hersien en verander. Binne hierdie proses word die waarnemingsveld op 'n kognitiewe wyse herhaaldelik herskep. So 'n beskouing bied 'n raamwerk waarbinne "literatuurgeskiedskrywing", veral interkulturele literatuurgeskiedskrywing, as metakognitief beskou kan word. In plaas van 'n soeke na die "juiste" struktuur, word literêre geskiedskrywing 'n soeke na 'n verbeelde struktuur - 'n struktuur wat in die eerste instansie in ooreenstemming is met 'n mens se perseptuele modus eers in die tweede instansie in ooreenstemming is met die beskikbare gegewens. Hierdie uitgangspunte word beredeneer met betrekking tot SuidAfrikaanse literatuurgeskiedskrywing in Engels.

\section{Transcultural literary history within global contexts}

"Transcultural literary history", which just a few years ago one would have expected to see under the rubric of "postcolonial studies", appears to have been drawn into a bigger category in which the words global, world and multinational feature prominently. That this might be the case was recently suggested by the enthusiastic collaboration of scholars from across the globe in a symposium in Stockholm called "Studying transcultural literary history", part of a larger project backed by the Swedish Research Council called "Literary history in global contexts" 2 . In so far as symposia such as these, attended by leading figures in the world academy, point to trends and shifts in scholarly sentiment, it was conspicuous that the word postcolonial no longer carries much weight - indeed it was hardly even uttered at the symposium, and if it was present, there was a distinct sense of squeamishness about its deployment. At the same time, there appears to be a renewed appetite for projects conceived in terms that are consonant with "multinational", "world" and "global" literary studies. 3 This spirit is by no means expressed in terms that are innocent of the dangers of globalisation, but there is

2 An earlier version of this paper was presented at the Stockholm symposium.

3 For obvious examples of this trend, see Moretti (1998; 2000), and Damrosch (2003). 
nevertheless an urgent sense of wanting to press ahead with larger projects of benevolent integration and cross-mapping, in a spirit of celebrating world cultures.

When I received an invitation to participate in the Stockholm symposium, which promised to deal with transcultural literary history on a dauntingly global scale, I experienced two distinct and quite strong feelings: déjà vu and unsettlement. Déjà vu because it was almost ten years since I had been invited to a similar symposium to crack the nut of South African transcultural literary history, and unsettlement because I felt that literary histories were impossibly alluring, and alluringly impossible undertakings. They are certainly not everything they seem. If literary histories are shimmering expanses, then transcultural literary histories are a Sargasso Sea.

\section{The colonial-apartheid castle}

Why transcultural histories resemble a Sargasso Sea is perhaps suggested in the story I should tell about the South African symposium of ten years ago, and about its afterlife. The organisers of the event, called "Rethinking South African literary history" (held in Tongaat, Natal, under the auspices of the Centre for the Study of Southern African Literature and Languages in May, 1995), like their invited delegates, were sharply aware of the fact that the edifice of South African literary practice needed urgent renovation, perhaps even all-out attack. As literary academics, we had entered full democracy for the first time in our own lifetimes, yet we continued to inhabit the unequal inner chambers of the colonial-apartheid castle. In this hoary old structure, English and Afrikaans-language literature had dominated the grand ballrooms of literary reception, enjoyed most of the dealings with the agents of dissemination, evaluation and patronage, and danced with the greatest number of readers to the music of public approbation. When the colonial castle was captured by Afrikaner nationalism in 1948, after 250 years of occupation by interests aligned more to English than to any other language, it was renovated but its structures were not greatly changed. What had become known as "Bantu" literature, and promoted as such by missionaries (cf. Shepherd, 1936; 1945; 1955), was now kept in service closets, to be hauled out for ideological uses in a system called "Bantu education". Further back down the passageways of the castle, in its musty basement store-rooms, one might find the remains of long-dead Bushman voices, in one famous instance transcribed and translated into Victorian English (cf. Skotnes, 2004), and the many records of cultural persuasion, 
conversion and contestation, dating from the time when converging power allowed the coin of social exchange to be struck in the metal of European modernity.

\subsection{Unequal literary stratifications}

By the time we got to Tongaat in 1995, we were still living in the wake of these conditions, and we still taught within the unequal linguistic stratifications into which we had been born. Many of us had been involved in liberating South African English writing from the stranglehold of colonial lordship, but the scene of literary accomplishment - the vast old castle with its cultural treasures and its lesser goods spread around in nequal amounts - was something we could not continue to leave untouched. We were tired of that particular structure, tired of its routines, its well-trodden passageways, its dark antechambers, its shadowy lords and fickle patrons. We wanted to launch a fresh assault.

But we were trapped inside its structures. Our university disciplines were based on the old taxonomies, many of us were products of bilingual rather than multilingual educations, and we ourselves did not have the means to change publishing practice or decades of sense and sensibility in the classrooms and in literary appreciation. The material structures of our entire literary practice, in all its uneven distribution, were big and difficult to pull down. We were not Samsons.

And so, like true academics, we turned to "history". We could not storm the castle, but what we certainly could do was review it, walk out into the fields and take a good, long, hard look at it. Name the parts. Rearrange the inventory. The Tongaat organisers, particularly Johan van Wyk, wanted the entire project to culminate in an encyclopaedia of South African literary history, a great revolutionary leveller in which all the lost voices would be allowed to sing out their diversity in full throat, standing in the same row as the known and the celebrated.

\subsection{A suspicion of metanarratives}

The ideal to enclude all lost voices in one encyclopaedia was, however, never going to be that easy. By an exquisite irony, the strong encyclopaedic urge at Tongaat coincided with an equally powerful "postmodern" exhaustion with metanarratives. This irony was as delicate as global Communism giving up the ghost at just the moment that the South African socialist revolution belatedly got 
ready to command the stage of real power. In literary historiography, the desire to make amends by naming all the parts and adding them up equally was tainted by a well-justified suspicion of national narratives, "totalising" versions and historical set-ups. We had seen too many of them in South Africa.

It is true that the postmodern pulse throbbed rather belatedly in South Africa, and it was certainly hotly contested by those who, understandably, wanted to keep their eyes on the horrible real and not see it refracted into simulacra, but South Africans nevertheless had good reason to be suspicious of metanarratives. After all, we had only just emerged from the sickly totalising grand recit of modernity in at least two perverse guises: the colonial-missionary kind, in which the prototype of an English gentleman necessarily involved a high degree of ethnic stripping; and the metanarrative of apartheid, with its tendency to assign identities to people by hypostatised ethnic categorisation within a "modern" taxonomy of "Bantu studies"-type anthropology ("Volkekunde", grounded in social Darwinism) - an exercise in which the act of stripping was reversed. This time, South African indigenes were told to tear off the hand-medowns of cosmopolitan modernity and go back to their (various) tribal skins. Just like the colonial strip, it did not entirely work, and it created many interesting examples of self-fashioning against the grain, but the grand narratives, backed as they were by the orchestration of significant power and material effect, had created considerable human suffering.

It was not lost on those Tongaat delegates of a "theoretical" persuasion (cf. Morphet, 1997:73) that the "nation" was suddenly brand new, an imagined tabula rasa upon which new narratives were already being written. The "theoretical" delegates were therefore alarmed by the looming and hidden implications of an encyclopaedic approach to literary history. Certainly, the organisers were hardly naïve - they too wished to celebrate the carnivalesque, discover diversity and knock down the castle walls so that everyone could join the party - but there was something deeper at issue. This is the very possibility, or the desirability, of pursuing literary history as an encyclopaedic act in the first place, with all its attendant implications of coverage and completeness.

\section{What does dit mean to do "literary history"?}

At this point in the line of argument, I want to take leave of the Tongaat story for a moment and consider the elements in play. 
What does it mean to do "literary history" at all? Every act of literary history involves collecting data which is, of necessity, incomplete unless the field is very strictly demarcated, although such very strict demarcation weakens the claim to "history". Thus, in the (usually) less tiny narratives of literary history, there is an inevitable supplement. The data is vast, spread out and far-flung. Once collected by a process of selection, it is arranged, thematised and organised into narrative shape, regardless of the ever-looming supplement which silently but ineradicably subtends the proclaimed history.

\section{- Signs are contingent, culturally embedded and historically influenced}

However, I do not wish to offer the above as a novel insight. We have already come to accept the Derridean supplement and most of us have accommodated ourselves to the whole movement of poststructuralism, towards an acceptance that signs are contingent, culturally embedded, historically influenced and generally quite slippery. We have taken this in. Few of us would wish to be associated with a position that simply or straightforwardly equates the word with the world.

\section{- Historical narratives cannot escape the condition of their own tropology}

Literary history, in particular, has been in a position not only to assimilate the insights of poststructuralism, to embrace the rhizome as a metaphor rather than the beanstalk that grows to the sky, but also to receive the benefits of a theorist of historical narratives such as Hayden White, who has argued persuasively that historical narratives cannot escape the condition of their own tropology, and that their textual constructedness is the prime condition of their existence (cf. White, 1973).

However, much as we might say literary-historiographical practice has absorbed the lessons of the rhizome, that it eschews foundationalism in favour of traces and knows it must remember that tangled masses of subterranean root-systems lie just beyond the more systematic crops of planned intellectual mapping and cultivation, there is a prior step in the process that appears, often, to 
be overlooked, both by the "theory" camp and by the "professional" camp, ${ }^{4}$ not to mention those in between.

\section{- The complexity of cognitive processes}

I hesitate to say this, so obvious does it seem, but the step that is often overlooked in the literary-historiographical practice is cognition - the processes of consciousness that allow us to create a mental representation in the first place. Cognitive studies, which finds a particular focus in experiments with and studies in artificial intelligence (Al), confront the question: how does the brain make sense of what it perceives via the sense organs? Al researchers have been forced into an awareness of the stupefying complexity of cognitive acts, because they have tried to replicate them with computer programs, and they have realised how far off humans are from understanding even the most basic cognitive processes, such as, to quote an outrageous example, the information, know-how, discrimination, elimination, assessment, cultural and scientific data entailed in the making of a midnight snack (Dennett, 1998:187192). 5

Further, Al makes it clear that the processes of cognition cannot be overlooked. That is, no knowledge about the world - and about literary history, in our case, which is doubly complex - can be assumed as an entity that is in any way separate from the processes of cognitive patterning that go into its shaping by human minds. Now this may seem a truism, but if you then consider that - as both Daniel Dennett (1998:241) and Douglas Hofstadter (1995:63) persuasively argue, cognition is fundamentally analogical and that patterns are discerned by our minds in the raw data confronting our senses via the imagined, guessed-at correspondences with, and differences to other cognitively constructed patterns - then literary history becomes a play of the precise and the imprecise, of the provisional datum at hand and the imagined possibilities of its working interrelations, its inner secrets.

4 Tony Morphet (1997:73) categorises the two "camps" at the Tongaat symposium as adhering to a "theoretical" discourse on the one hand, and a "professional" discourse on the other.

5 For an introduction to the "cognitive turn" in literary studies, see "Literature and the Cognitive Revolution", a special issue of Poetics Today (Richardson \& Steen, 2002). 
Hofstadter (1995) argues that even the "known", the perceptual data one encounters in the world, is shaped by analogical thinking. "Not only, then, is perception an integral part of analogy-making, but analogy-making is also an integral part of perception", Hofstadter (1995) argues, adducing much evidence and exhaustive argumentation that readers may wish to examine independently. Hofstadter (1995:186) gives the following simple example: if one perceives Saddam Hussein as analogous to Hitler, the perception of an evil, aggressive figure is formed. If, however, one perceives Saddam as a Robin Hood, redistributing the superfluous wealth of the Kuwaitis to the rest of the Arab population, a relatively generous figure emerges.

\section{- Perception and analogy are inseparable cognitive acts}

I would like to add what I believe is a critical element to Hofstadter's argument that perception and analogy are inseparable cognitive acts. For me, it is hard to imagine the processes of cognitive patterning via analogical perception (or perceptual analogy) without the "colouring" of feeling. How exactly feeling is entailed cognitively - whether one perceives Saddam as a Hitler because one has a prior feeling impelling one towards such an analogy, or whether the perceptual-analogical process itself produces such a feeling, calling it into being - is a matter for speculation. But feeling, particularly ideological feeling, is strongly entailed in the semantics of analogical perception, as the article seeks to demonstrate below.

To recap, then: to say that cognition is analogical is to say that it is metaphorical - that one thing is seen in terms of another (or an aggregate of other things). If one adds feeling, or ideological inclination expressed-as-feeling to the Dennett-Hofstadter theory of cognition and analogy, then we may postulate a model of cognition in which metaphor - more accurately - choice of metaphor, is not only a constitutive element, but to a large extent influenced by one's feeling about the data at hand.

In this argument, the processes of analogical-metaphorical cognitive processing via feeling precede the question of whether one is a poststructuralist or a hard-nosed recorder of the stuff that is undoubtedly out there. Whatever one's inclination, one's style or model, whatever one's attitude to literary history or "theory", one cannot escape cognition. One cannot get around the fact that processes of cognitive assemblage must occur in order to shape one's material according to one's sense of the fitness of things. 
Cognitive assemblage is the shaping process. It is the way one feels about things.

\section{- Perceptions create a literary field: "scrapyard" versus "archipelago"}

Should one accept that cognitive assemblage implies a shaping process, allow me to offer instantiation from my own field of study. Were you to consider South African literature, in historical review, as a scrapheap, as Pinchuk did in 1963, then a very distinct and compelling organisational picture emerges. Pinchuk (quoted in Gray, 1979:7) writes:

It is impossible to find a principle of unity in South African writing yet inevitable that one should seek it. To me it suggests the picture of a scrapyard where the only seeming relationship between the scattered arrangements of metal, wood, soil and grass is that they are all contained within the same area.

No matter how unwelcome one may find Pinchuk's analogy, it evocatively concretises many key elements often perceived in a South African literature: its disparate origins, its uneven quality, the incommensurability of its parts, its many crashed experiments, grandiose designs, heterogeneous make-up, and so on. The overall cast of the analogy, however, suggests a sub-field, a derivative place of cast-off "scrap" in relation to a "normal" or normative field elsewhere. This in turn tells us, with uncommon economy, a lot about Pinchuk's presuppositions about the relation of South African English writing to English writing in the metropolitan world.

In 1963, when Pinchuk was writing, it was more or less the going feeling in the South African English academy that local writing was a forlorn affair. Pinchuk's analogy is useful to us today if we are doing a survey of South African literary historiography, because it tells us so much about culturally conditioned modes of cognition about the literature, rather than the literature itself.

For a long time, the study of South African literature was stymied by precisely such emotionally laden perceptions of local writing as being second-hand and "colonial" - derivate, imitative, presumptious, non-"universal". The perception made the field. It cast a cognitive, sensemaking, semantically-laden history over the field, if you like, a history which - in Michael Chapman's very serviceable analogy of literary value - was highly "usable" (Chapman, 1996:15 ff.). It served many purposes, from the ideological to the spiteful. It 
allowed academics, "scholars", blithely to ignore indigenous literature that was everywhere around them.

In the event, it took an enormous effort of perception-battering to change this sentiment about the make-up - the cast and quality - of South African literature, this sense of its history. One of the most influential agents in the process of re-engineering the semantics, and the sentiment, around "local writing" in South Africa was Stephen Gray, and he did it by creating a new, evocative, elaborately constructed and arguably better analogy for the field of South African writing: the archipelago. This is how Gray summed it up in his landmark book, Southern African literature: An introduction:

The guiding metaphor for this introduction is that Southern African literature is like an archipelago. The islands with their peaks protrude in set positions, even if one does not readily see the connections between them beneath the surface. Like most archipelagoes, it is related to adjacent landmasses: in this case there are three of them - most importantly, the mainland of English literature, by language and historical circumstance; diminishingly, the British Commonwealth of literature; and increasingly, the continent of Africa which gives it its actual nourishment. Although these three realms condition its location, that is not to say it does not have an independent life of its own ... Its various pinnacles may have been described every so often, but what it is necessary to chart now is what tides and drifts and spins, what internal interconnections, have made them the way they are (Gray, 1979:14).

Gray's analogy, backed up by scholarship and physical campaigning for the cause of South African writing, made a big impact in turning around perceptions and feelings. The analogy itself was key to Gray's project. Hofstadter argues (1995:63) that "analogy-making lies at the heart of pattern-perception and extrapolation ... patternfinding is the core of intelligence ... [and] analogy-making [therefore] lies at the heart of intelligence". Gray's metaphoric reshaping - one is tempted to call it cognitive reformatting - of the field of Southern African literature demonstrates precisely such extrapolation, patternfinding and critical intelligence. Through the organising power of the analogy Gray uses, he is able to offer an alternative to the "scrapyard" analogy, and thereby offer his readers a better stab at the possible shape of the enormously variegated data that make up the field of literary history he is dealing with. The incommensurability of elements in the field changes from a heap of junk, suggesting desuetude, to an organic metaphor rich in movement and life: the churning currents of the sea holding within its fresh clasp islands of 
tropical diversity. Suddenly one's perception of the field is transformed.

The record also suggests that a new generation of literary scholars in South Africa following Gray and similar campaigners went out with changed analogical-perceptual cognitive processing and created a literary field, along with new literary "histories", new senses of, and feelings about the "field". A revised semantics had become possible. The datum of the field had always been there, and was growing by the day, but it was now being cognitively perceived as a field, a rich and fertile and enormously interesting ground, and only by virtue of such perceptual-analogical moves was it able to become a metaphenomenological construct, a "history" of things in the world, a history with weight and dignity.

\section{Is the venture of an encyclopaedia appropriate or possible?}

In attempt to provide an answer to the above issue I need to return to the Tongaat symposium: during our debates it soon became clear that the underlying issue was not how to construct an encyclopaedia of South African literature, when and by whom, but whether such a venture was appropriate or even possible. People of the so-called "theoretical" persuasion, myself included, held that an encyclopaedia was an impossible idea, an over-reacher's dream, like Borges's lifesize map of an imaginary empire which coincides with the empire's territory point for point (Borges, 1972:325). What purpose would it serve to match the data point for point? The matter is out there, available for measurement via the usual tools. All it takes is some hard work. Why destroy the joy of discovery by naming the parts under a single regime of information?

But those of us who felt uncomfortable with the encyclopaedia idea also held the opinion that an encyclopaedia, in the true sense, was in all likelihood physically impossible too. The data would always exceed the parts already named - not only because the data physically exceed the capabilities of those trying to gather it all in, but, as in the poem in my intertext, Henry Reed's "Naming of Parts", the very act of naming itself would irresistably become diverted into tropology, sidetracked into metaphor.

In fact, I am now convinced that the adherents of the "encyclopaedia" approach as a way of ironing out the inequalities of South African literature were themselves using the term encyclopaedia more metaphorically than factually. Consider the subsequent events. 
The Tongaat symposium was followed up by two further gatherings at the University of Essen, the first called "South African literary history - totality and/or fragment" (1996), and the second under the rubric "Constructing South African literary history" (1998). The papers at these two gatherings show an increasing tendency to move away from "encyclopaedic" accounts, seeing literary history as constructed, or offering more discrete case-studies that concentrate on smaller and manageable topics.

\section{- The encyclopaedia idea in a changed shape}

In the event, however, the encyclopaedia idea had not disappeared, but changed shape instead. A collaboration between Johan van Wyk, principal mover behind the Tongaat and Essen symposia, and Graham Stewart, an information science researcher, saw the development of a prototype hypertext program captured on what they called the SALit CD-ROM. This was a conceptually brilliant move. Accounting for South African literary history in terms of linear narrative had always been a major stumbling block. The switch to the open-ended spaces of hypertext, which are multidimensional, non-sequential, lateral and inexhaustible, suddenly provided a model that, theoretically, might cope with the linguistic disparateness, the incommensurability of forms, the blinding diversity of topics and the supplement of data perceived to be in the field under study. At a conference in Port Elizabeth in the year 2000, Van Wyk and Stewart declared that their project was aimed at producing an encyclopedia of South African literature "designed to transcend the limiting categories of language and race of the past" (2000:1). In their paper, Van Wyk and Stewart cite Foucauldian discourse analysis, postcolonial theory and hypertext theory as integral to their model, and declare their affiliation to non-linearity by invoking Deleuze and Guattari's metaphor of the rhizome (2000:2).

However, since the announcement of this project and some papers written on it, not a lot has happened in database terms. The project's extant traces can be found on http://salit.dit.ac.za under the general heading "South African Literature Online", and it offers three portals: a literary map of KwaZulu Natal supplying basic information about writers and their locales in KwaZulu Natal; an "encyclopaedic database" called SA Lit web; and a database called "SA Literature Online". By Stewart's own admission, the databases remain "idiosyncratic" and have not been developed much beyond prototype stage. They are replete with what a librarian I asked to survey the portals calls "black holes". When I phoned Stewart, he readily conceded that the project needed more resources and networking. 
Professor Van Wyk, Stewart told me, had suffered a stroke and had left full-time academic life. He was, nonetheless, labouring over the proofs of a textual version of his Encyclopaedia.

\section{- Hypertext as a metaphor for transcultural literary history}

Despite the apparent failure of the hypertext encyclopaedia, hypertext as a metaphor for transcultural literary history remains one of the best I have come across. It is certainly a breakthrough. One might argue that the hypertext project, rather than having failed, is simply incomplete; that being incomplete is a constitutive part of its nature. I would add that despite its manifest failure as an encyclopaedic database, it has already notched up what is perhaps its most significant achievement: its choice of metaphor. I look forward to seeing Van Wyk's narrative Encyclopaedia, should it be published. I am even more grateful to him for the idea of hypertext as a model for transcultural literary history, because it tells me so much more about the field than the field itself can tell me, reproduced in endless lists of books, records of writers and orators, capsule evaluations of works and trends - a map of the field seeking to stretch right across the field, point for point. 6

The story of the hypertext encyclopaedia and its failure is a deeply human one. It is suggestive of the struggle against disorder, only in this case a methodology of "organised" disorder (rhizomatic, hypertext-based multilateral information) itself came up against the larger, centuries-old supplement, as indomitable as Adamastor himself. Yet it provided a way of looking, an alternative model for literary historiography in South African letters. And it left space for more assaults on the mountain. It gave us a crucial new metaphor. And that is the whole point.

\section{- Literary historiography as a serial act}

Literary historiography, particularly in a cross-cultural frame, cannot be conceived as an act that can be completed, or even provisionally completed. It is a serial act, a necessarily self-revising cascade of analogical windows which, in an important sense, recreate the field cognitively - and recreate feelings about the field - over and over again. Our understanding is not of the "field" itself, whose history

6 A hypertext model of literary history should not be confused with a mere database, which some delegates at the Stockholm symposium tended to do. Hypertext can carry (many, not necessarily continuous) narratives just as well as it can contain data. 
must be "more correctly", or "more deeply" written up, our understanding is metacognitive: it is an understanding of our understanding of the intractable datum of the "field" at any given moment. Further, it is an understanding that our given understanding at any moment in time is contingent and cognitively (inter)changeable. In such a context, literary history is transformed from the search for "true" structure and feeling to a search for imagined structure and feeling, which is "true" to one's mode of perception in the first instance, and to the datum at hand in the second.

The difference is subtle but important. The datum is always at a remove. We should not seek to eliminate this remove by presenting our literary histories as the thing itself, although we are in fact guessing at the shape of the thing itself. It is precisely because of this tantalising gap, this speculative cognitive zone of inspired perceptual-analogical invention, that "history" - and transcultural literary histories in particular - become interesting.

\section{List of references}

BORGES, J.L. 1972. A universal history of infamy. Trans. by Norman di Giovanni. New York: Dutton.

CHAPMAN, M. 1996. Southern African literatures. Essex: Longman.

DAMROSCH, D. 2003. What is world literature? Princeton: Princeton University Press.

DENNET, D.C. 1998. Brainchildren: essays on designing minds. Cambridge: MIT.

GRAY, S. 1979. Southern African literature: an introduction. Cape Town: David Philip.

HOFSTADTER, D.R. (with the Fluid Analogies Research Group). 1995. Fluid concepts and creative analogies: computer models of the fundamental mechanisms of thought. New York: BasicBooks.

LEHMANN, E., RECKWITZ, E. \& VENNARINI. L., eds. 1998. South African literary history: totality and/or fragment. Essen: Die Blaue Eule.

LEHMANN, E., RECKWITZ, E. \& VENNARINI. L., eds. 2000. Constructing South African literary history. Essen: Die Blau Eule.

MORETTI, F. 1998. Atlas of the European novel, 1800-1900. London: Verso.

MORETTI, F. 2000. Conjectures on world literature. New Left Review, 1:55-67.

MORPHET, T. 1997. Rethinking our rethinking. Scrutiny2: Issues in English Studies in Southern Africa, 2(1):71-75.

PINCHUK, I. 1963. The South African image. Purple Renoster: 5, Summer. (Cited in Gray, 1979.)

RICHARDSON, A. \& STEEN, F.F., eds. 2002. Literature and the cognitive revolution. Special issue. Poetics Today, 23(1).

SHEPHERD, R.H.W. 1936. Literature for the South African Bantu: a comparative study of Negro achievement. Pretoria: Carnegie.

SHEPHERD, R.H.W. 1945. Lovedale and literature for the Bantu. Alice: Lovedale. 
SHEPHERD, R.H.W. 1955. Bantu literature and life. Alice: Lovedale.

SKOTNES, PIPPA. 2004. "Civilized off the face of the earth": museum display and the silencing of the /Xam. (In De Kock, L., Bethlehem, L. \& Laden, S., eds. South Africa in the global imaginary. Pretoria: Unisa. p. 32-56.)

SMIT, J., VAN WYK, J. \& PHILIPPE-WADE. J. 1996. Rethinking South African literary history. Durban: Y. Press.

VAN WYK, A.J., \& STEWART. G. 2000. The SALit CD-ROM: a virtual library of South African literature. Paper presented at CITTE. (Conference on Information Technology in Tertiary Education), 28-30 June, Port Elizabeth.

WHITE, H. 1973. Metahistory: the historical imagination in nineteenth-century Europe. Baltimore: Johns Hopkins University Press.

\section{Key concepts:}

analogy

cognitive processes

hypertext

metaphor

South African literary historiography

transcultural literary historiography

\section{Kernbegrippe:}

analogie

hiperteks

kognitiewe prosesse

literatuurgeskiedskrywing, Suid-Afrikaanse letterkunde

metafoor

transkulturele literatuurgeskiedskrywings 
